\title{
Rigid polyurethane foam composites with nut shells*)
}

\author{
Milena Leszczyńska1),**), Joanna Ryszkowska1 ${ }^{1)}$, Leonard Szczepkowski ${ }^{2)}$ \\ DOI: dx.doi.org/10.14314/polimery.2020.10.8
}

\begin{abstract}
Composites of rigid polyurethane foams were manufactured using ground peanut, hazelnut, walnut and pistachio shells. The aim of this study was the development of environmentally-friendly materials as well as investigation of the influence of the chemical structure, size and morphology of the filler particles on the processing parameters of the developed foams as well as their structure and physico-mechanical and thermal properties. The used fillers were precisely characterised, the viscosity of the polyol premixes have been examined and the characteristic times of the foaming processes have been investigated. The developed materials were studied using the differential scanning calorimetry, thermogravimetry, scanning electron microscopy, infrared spectroscopy and by determination of their apparent density, friability, water absorption and dimensional stability. The presented research results indicate that the agro-food industry waste could be a valuable source of raw materials for the production of rigid polyurethane foam composites.
\end{abstract}

Keywords: rigid polyurethane foams, natural fillers, nut shells, biocomposites.

\section{Kompozyty sztywnych pianek poliuretanowych z łupinami orzechów}

Streszczenie: Kompozyty sztywnych pianek poliuretanowych wytwarzano z zastosowaniem rozdrobnionych łupin orzechów: ziemnych, włoskich, laskowych oraz pistacjowych. Celem pracy było otrzymanie materiałów przyjaznych dla środowiska oraz określenie wpływu budowy chemicznej, wymiarów cząstek i morfologii napełniaczy roślinnych na parametry przetwórcze mieszanek oraz na strukturę i właściwości fizyko-mechaniczne i termiczne wytworzonych pianek. Szczegółowo scharakteryzowano zastosowane napełniacze, określono lepkość przedmieszek poliolowych oraz czasy charakterystyczne dla procesu spieniania. Analizy wytworzonych materiałów dokonano z zastosowaniem różnicowej kalorymetrii skaningowej, termograwimetrii, skaningowej mikroskopii elektronowej, spektroskopii w podczerwieni, a także na podstawie wyznaczonej gęstości pozornej, kruchości, chłonności wody i stabilności wymiarowej. Przedstawione wyniki badań wskazują na duże możliwości wykorzystania odpadów przemysłu rolno-spożywczego do wytwarzania kompozytów sztywnych pianek poliuretanowych.

Słowa kluczowe: sztywne pianki poliuretanowe, napełniacze naturalne, łupiny orzechów, biokompozyty.

An important advantage of using polyurethane (PUR) materials is the ability to control their physical, chemical and mechanical properties. Wide possibilities of modification within the raw material contents and adjusting the synthetic procedures allow for preparation of products suitable for construction, automotive, furniture, clothing and packaging applications as well as in cosmetics indus-

\footnotetext{
1) Warsaw University of Technology, Faculty of Materials Science and Engineering, Wołoska 141, 02-507 Warsaw, Poland.

2) FAMPUR Adam Przekurat Company, Gersona 40/30, 85-305 Bydgoszcz, Poland.

*) Material contained in this article was presented at the Science and Technology Conference on "Polyurethanes 2019", Ustroń, Poland, 13-16 October 2019.

**) Author for correspondence:

milena.leszczynska.dokt@pw.edu.pl
}

try or medicine $[1,2]$. High demand for the polyurethane materials and the growing ecological awareness lead to the quest for novel eco-friendly solutions for raw materials $[3,4]$. Moreover, apart from the desired limitation of the petrochemical raw material consumption, another relevant issue is related to the utilisation of the large amounts of waste generated during the industrial-scale food production $[2,5,6]$. Sustainable development, as a series of economic, social and environmental solutions aimed at preventing the natural resources depletion and maintaining the balance between the profits and costs of these developments, has currently became one of the leading goals of the European Union [7, 8]. The increasing costs of storage and utilisation of the agricultural industry post-production waste related to the increasing environmental protection results in a need for solutions allowing for the waste reutilisation. Consequently, the use of 
post-production residues as natural fillers (NF) for the production of green polymers has become the subject of interest for numerous research teams and entrepreneurs [9]. The natural vegetable fillers are commonly acquired from seeds, shucks, shells as well as fruits, leaves and stalks of various plants [10]. The advantages of natural fillers over synthetic fillers are numerous, including easy availability, low cost, low density, recyclability, renewability, biodegradability and less health risks [11]. The literature reports demonstrate the use of natural fillers such as: jute, sisal, cotton, banana, coir, hemp, rice husk ash, orange peel, as well as others in order to improve the properties of polyethylene, polylactide, polypropylene, epoxide resins and polyurethanes [9, 11-15]. The properties of vegetable fillers together with their abilities to reinforce the polymer materials are determined by their physical structure, including various levels of porosity, layering, shape and size as well as chemical content which involves mainly cellulose, hemicellulose, lignin and also fats, proteins, tannin, dyes, minerals and water [5, 16-18]. Investigation of the filler properties gives an indication of possible influence on the composite qualities which can be derived from the chemical content of the additive [19]. For example lignin exhibits hydrophobic properties preventing the natural fibers from swelling and microbial activity while the presence of cellulose enhances the mechanical strength of natural additives and increases hydrophilicity similarly to the hemicellulose. Cellulose is resistant to oxidation, alkalis and hydrolysis, while hemicellulose readily dissolves in alkali solutions and undergoes acidic hydrolysis [13]. Inside the natural filler, there may also be water retained as a result of processes aimed at maintaining proper hydration of the plant. Water content in plants depends on its type, tissue, organ, age and physiological state of the plant. Importantly the natural filler water content and release dynamics can have a vital influence on the properties of the biocomposite, particularly in the case of production of the porous polyurethane materials, where water acts as a porophore upon reaction with the isocyanate $[2,5]$. The researchers have already attempted to use natural fillers as reinforcement in the polymer composite but they have to face the challenges of higher moisture absorption, deterioration of the mechanical properties and poor adhesion between filler and polymer matrix [11]. Nevertheless, numerous publications suggest that proper preparation of the filler particles, analysis of their chemical composition, morphology and size followed by determination of the impact of the natural additives on the properties of the biocomposite allows for identification of the profitable directions of the recipe modification, leading to the products of high application potential [12, 20-22].

This study was designed towards the development of new, environmentally-friendly rigid polyurethane foam (RPUF) composites with hazelnut, walnut, pistachios and peanut shells used as natural filler and analysis of the influence of the chemical structure, grain size and mor- phology of the natural fillers on the processing parameters of the mixtures and on the structure, physico-mechanical and thermal properties of the developed foams.

\section{EXPERIMENTAL PART}

\section{Materials}

Rigid polyurethane foam composites have been synthesized using the following substrates:

- Rokopol ${ }^{\circledR}$ RF551 (polyether, sorbitol polyol, hydroxyl number $420 \mathrm{mg} \mathrm{KOH} / \mathrm{g}$, water content max. $0.10 \mathrm{wt} \%$, acid value max. $0.10 \mathrm{mg} \mathrm{KOH} / \mathrm{g}$, purchased from PCC Rokita, Poland) - 50 pbw (parts by weight);

- Rokopol ${ }^{\circledR}$ G500 (polyether, polyoxyalkylene triol based on glycerine, hydroxyl value $300 \mathrm{mg} \mathrm{KOH} / \mathrm{g}$, water content $0.10 \mathrm{wt} \%$, purchased from PCC Rokita, Poland) -50 pbw;

- TEGOSTAB B4900 (silicone surfactant, produced by Evonik Industries, Germany) -0.25 pbw;

- $50 \%$ urea solution in water $-2.75 \mathrm{pbw}$;

- Ongronat TR 4040 (mixture of methylene diphenyl diisocyanate (MDI) isomers and oligomeric MDI, containing $32.6 \mathrm{wt} \%$ of free isocyanate groups purchased from BorsodChem company, Hungary) - isocyanate index 106.

Hazelnut shells, walnut shells, pistachios shells, peanut shells - a waste products from the food and agriculture industry - were supplied by an industrial partners involved in the processing of nuts. The natural fillers were mechanically ground using the Bosch and Młynpol company mills and were dried at $70^{\circ} \mathrm{C}$ in a temperature chamber.

\section{Synthesis of the composites of rigid polyurethane foams}

The synthesis of the rigid polyurethane foams was performed using a single-step method by mixing (1600 RPM, $10 \mathrm{~s})$ of the polyol premix containing polyols, surfactant, catalyst, porophore (PU_REF) and, in the case of biocomposites, $15 \mathrm{php}$ (parts per hundred parts of polyol) ground hazelnut shells (PU_HN), walnut shells (PU_WN), peanut shells (PU_PN), pistachios shells (PU_PC) with the isocyanate component. After adding the components the mixture was poured into the open mold. Next the foams were annealed for $30 \mathrm{~min}$ at $70^{\circ} \mathrm{C}$ and conditioned at $22^{\circ} \mathrm{C}$ and $50 \%$ relative humidity for $24 \mathrm{~h}$ before being removed from the mold. After two weeks the resulting foams have been cut and tested.

\section{Methods of testing}

- Ground natural fillers were subjected to the sieve analysis according to the polish standard PN-EN 933-10:2002.

- The dynamic viscosity of the mixtures was studied at $25^{\circ} \mathrm{C}$ using the shear rates of $0-70 \mathrm{~s}^{-1}$ using a Brookfield 
viscometer model DV-II + Pro, equipped with a measuring spindle type SC4-21. The reference polyol premix was prepared as a 1:1 mixture of Rokopol ${ }^{\circledR}$ RF551 and Rokopol ${ }^{\circledR}$ G500 polyols (RF551_G500) as well as the mixtures involving natural fillers using $15 \mathrm{php}$ content (RF551_G500_PN/HN/WN/PC).

- The content of easily volatilized substances in the fillers was determined using a moisture analyser from Radwag. Measurements were made in the temperature range $25-160^{\circ} \mathrm{C}$, using $2 \mathrm{~g}$ of samples.

- The filler and foam morphology was characterized using a Hitachi TM3000 scanning electron microscope. Before observation, the samples were dusted with gold using a Polaron SC7640 sputter coater. The process was carried out for 100 seconds at a current of $10 \mathrm{~mA}$. Observations of foam samples were carried out at an accelerating voltage of $5 \mathrm{keV}$, fillers were observed at a voltage of $10 \mathrm{keV}$. Based on the obtained SEM images of foams, equivalent pore diameters were determined, the analysis was performed using the ImageJ software.

- Thermogravimetric analysis was performed with the TGA Q500 TA Instruments using $10 \pm 0.5 \mathrm{mg}$ of samples which were heated in a nitrogen atmosphere from room temperature up to $830^{\circ} \mathrm{C}$ at the rate of $10^{\circ} \mathrm{C} / \mathrm{min}$. Data analysis was performed using the Universal Analysis 2000 software, version $4.5 \mathrm{~A}$, by TA Instruments.

- The characteristic times of the foaming process (start time, rise time and tack-free time) were determined using an electronic stopwatch. They were measured from the moment the components were mixed until: the beginning of the visible expansion of the reaction mixture by volume (start time), obtaining the maximum foam height (rise time), the moment when the foam surface became dust dry (tack-free time).

- The Fourier Transform Infrared Spectroscopy (FT-IR) study was carried out using a Nicolet 7600 (Thermo Electrone Corporation, USA). Spectra were recorded as a sum of 64 scans using a spectral range from $4000-400 \mathrm{~cm}^{-1}$. A baseline correction for $\mathrm{CO}_{2}$ and $\mathrm{H}_{2} \mathrm{O}$ was performed to eliminate the impact of the compound residues from the analysis. The results were analyzed using the OMNIC8.2.0 software by Thermo Fisher Scientific Inc.

- The DSC analysis of the PUR foams was performed using a differential scanning calorimeter Q1000 (TA Instruments, USA). Samples ( $5 \pm 0.2 \mathrm{mg}$ ) were closed in hermetic aluminum cups and heated at $10^{\circ} \mathrm{C} / \mathrm{min}$, cooled at $5^{\circ} \mathrm{C} / \mathrm{min}$ and heated again at $10^{\circ} \mathrm{C} / \mathrm{min}$.

- The apparent density and friability of the RPUFs were determined according to ISO 845 and ASTM C-421 respectively.

- The water absorption was performed at elevated $\left(40^{\circ} \mathrm{C}\right)$ temperature and the dimensional stability after immersion of the samples was tested $\left(40^{\circ} \mathrm{C}, 24 \mathrm{~h}\right)$. Three samples of each material with size of $50 \times 50 \times 25\left(\mathrm{~mm}^{3}\right)$ were weighed, measured and immersed in water for $24 \mathrm{~h}$. Afterwards, the samples were removed from the water and subjected to the second measurements of weight and size. The resulting water absorption was calculated as the volume ratio of the absorbed water to the initial volume of the sample while the dimensional stability was determined as the ratio of difference in size before and after the procedure to the initial size in an orientation parallel to the foam growth direction.

\section{RESULTS AND DISCUSSION}

\section{Analysis of the natural fillers and the processing parameters of the premixes}

\section{The sieve analysis of the natural fillers}

The sieve analysis results clearly indicate that the fillers $\mathrm{HN}$ and $\mathrm{WN}$ were characterized with the highest degree of fragmentation $(\sim 60 \%$ fraction $<45 \mu \mathrm{m})$. The grain size

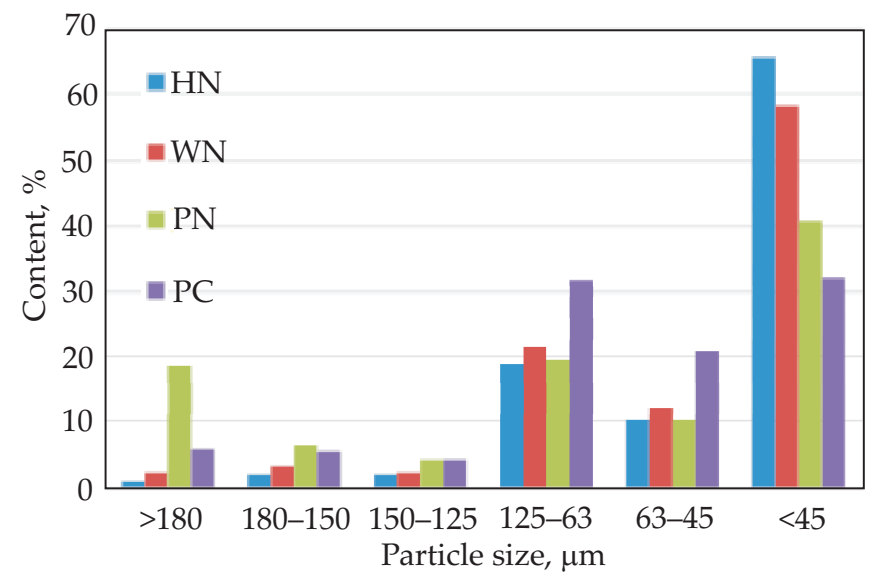

Fig. 1. The grain size analysis of the natural fillers

distribution of the PN filler is uneven with $~ 19 \%$ fraction $>180 \mu \mathrm{m}$. PC screening analysis indicates $85 \%$ fraction $<125 \mu \mathrm{m}$ (Fig. 1).

\section{Analysis of the filler particles surface morphology and the viscosity of the polyol premixes with the natural filler particles}

The introduction of the natural filler particles into the PUR composition significantly alters the viscosity of the premix, which is additionally affected by the filler particles size, shape and surface area. Therefore the viscosity of the premixes with vegetable additives was investigated (Fig. 2) as one of the major factors determining their processing capabilities.

The results of the viscosity study clearly indicate that introduction of the hazelnut shells and walnut shells as natural fillers resulted in a greater increase of viscosity in comparison to the pistachio shells. This observation is most likely related to the lower grain size of the $\mathrm{HN}$ and WN natural fillers compared to the PC filler. Moreover, an introduction of the PN filler resulted in the highest increase of the polyol premix viscosity despite the higher 


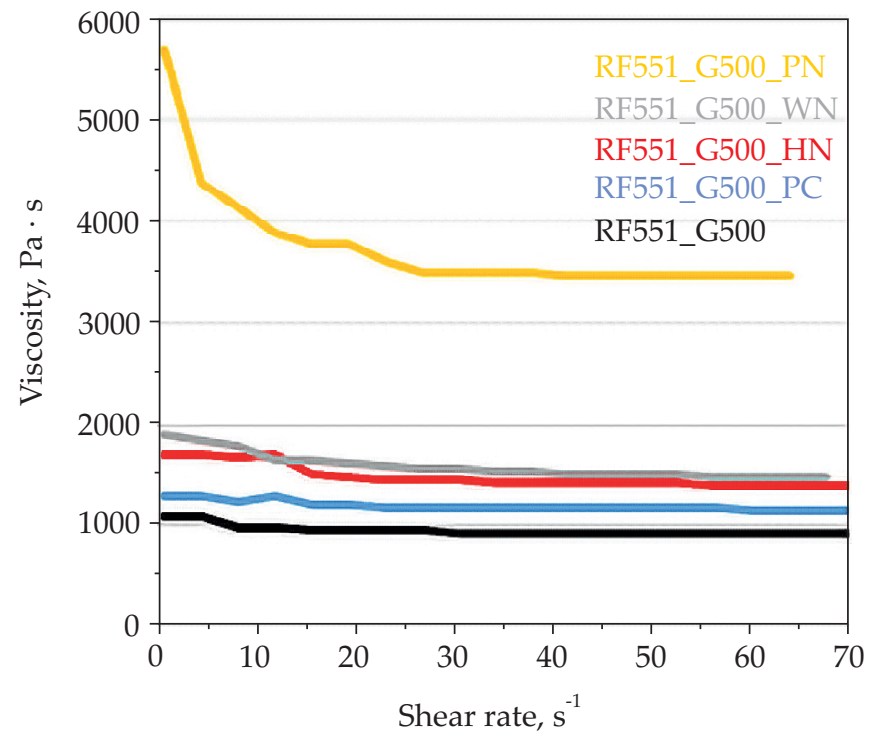

Fig. 2. Viscosity curves for reference mixture and premixes with natural fillers

content of the $>180 \mu \mathrm{m}$ grain size fraction as compared to the $\mathrm{HN}$ and WN fillers. In this case the probable explanation of the increased viscosity is related to the surface morphology of the filler particles (Fig. 3).
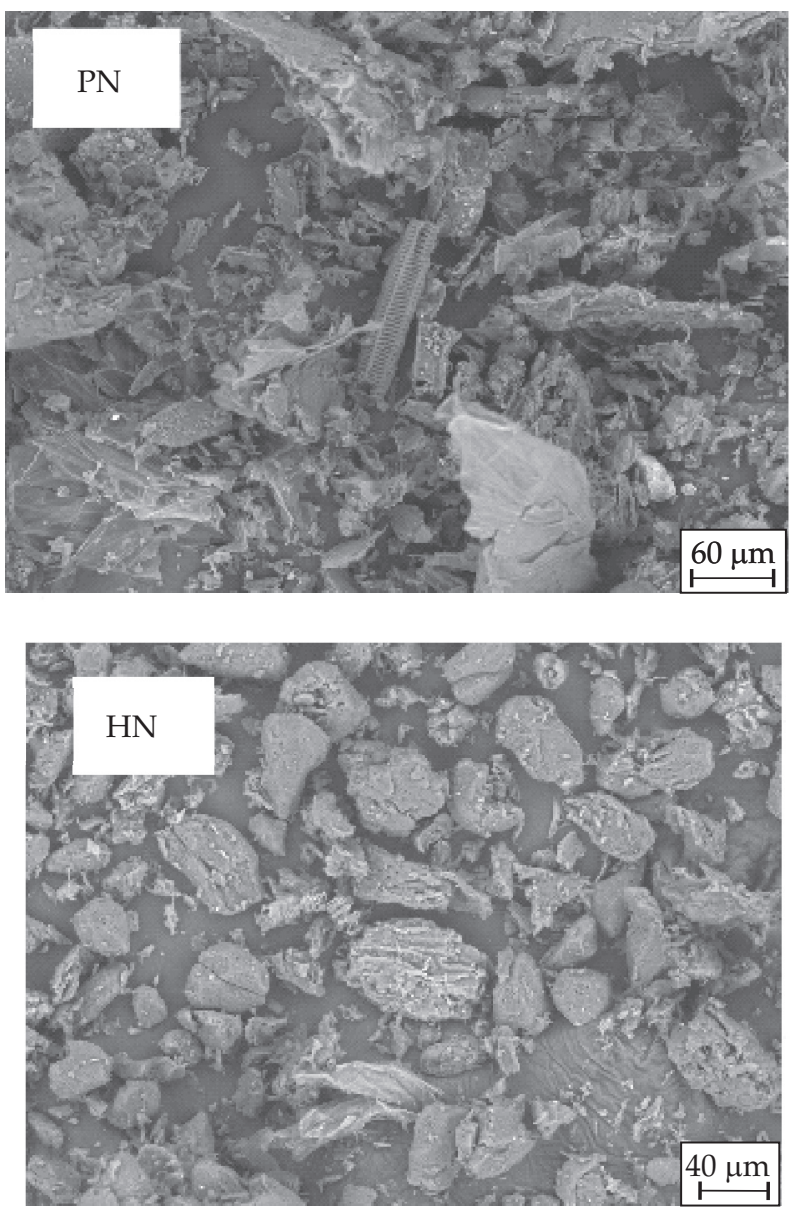

Indeed, the scanning electron microscopy imaging study revealed that the ground peanut shells used as natural fillers were characterized with varied size and a shape of irregular flakes (shreds) as well as more regular cylinders with partially conserved fibrous structure characteristic for to the plant-based materials. Moreover, the SEM images of PN filler particles revealed the significant surface development indicating high surface area, which explains the high increase of the viscosity of polyol premix containing the PN filler particles, as confirmed in similar cases reported in the literature [23]. The SEM images of the hazelnut, walnut and pistachio ground shells reveal similar structures, which are significantly different in geometry than the ones observed for PN filler. Apart from the fine particles of irregular shapes the SEM images of $\mathrm{WN}, \mathrm{HN}$ and PC fillers revealed the presence of oval grains resembling spheres of partially smooth and partially rough and porous surface. Moreover, the SEM images of the hazelnut ground shells also demonstrated the presence of spirally twisted cellulose microfibrils.

\section{Thermal analysis of the fillers}

In order to determine the amount of volatile substances in the natural fillers the mass loss measurements
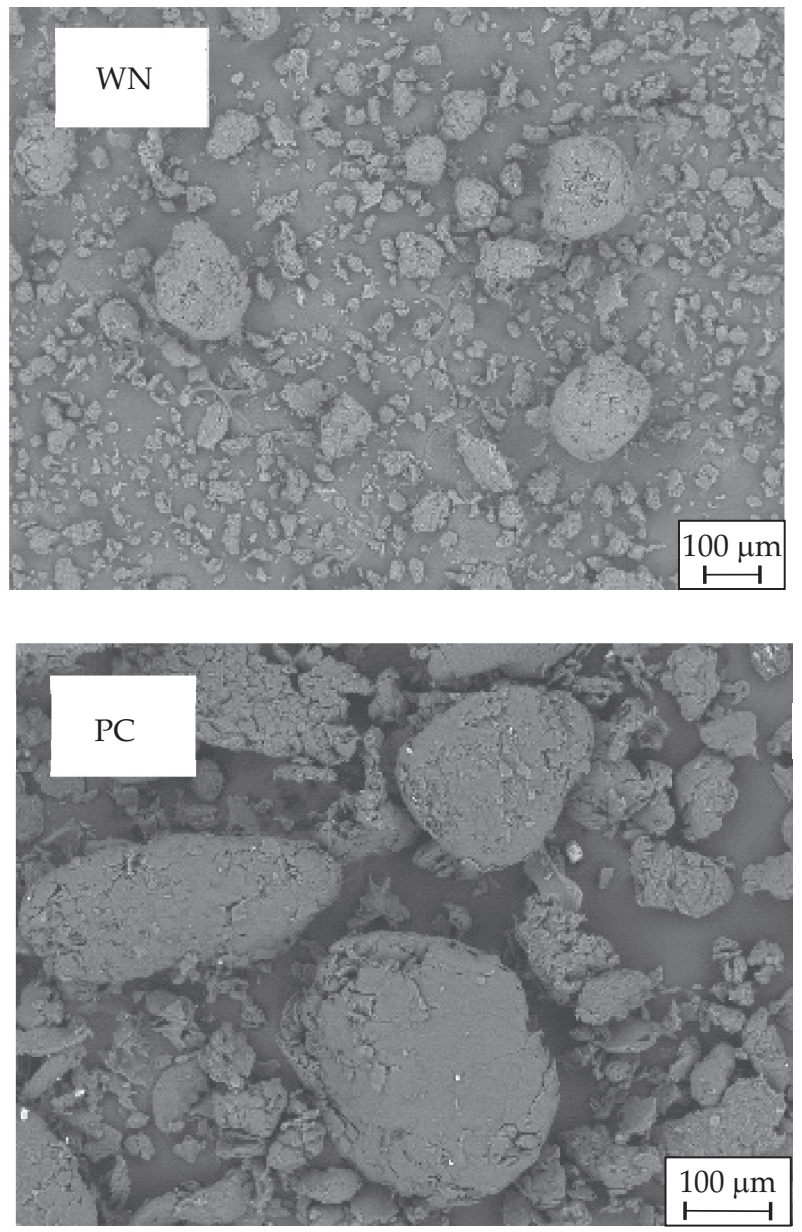


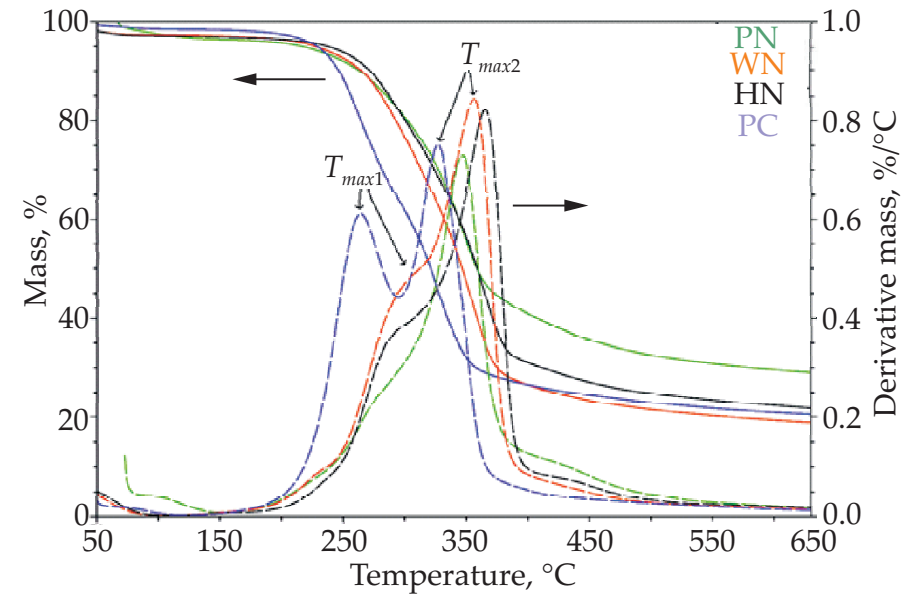

Fig. 4. TG and DTG curves of the natural fillers

of the pre-dried fillers were conducted using a moisture analyser. The measurements were conducted in the temperature range $25-160^{\circ} \mathrm{C}$ in order to account for the estimated maximum temperature in the foam block during the synthesis due to a possibility of releasing some substances from the filler particles during the foam synthesis process $[2,24]$. This study resulted in the following values of mass loss in the selected temperature range: $\mathrm{PN}=2.5 \%$, $\mathrm{HN}=2.2 \%, \mathrm{WN}=2.4 \%, \mathrm{PN}=2.0 \%$. The reason for the observed mass loss might be the presence of the hydration water in the plant-based materials, which requires high temperature drying processes to be removed.

The TG and DTG curves of the natural filler thermal degradation were presented in the Fig. 4.

According to the literature data the initial step related to the release of easily volatilised substances is followed by the decomposition of lignin $\left(190-500^{\circ} \mathrm{C}\right)$, hemicellulose $\left(220-315^{\circ} \mathrm{C}\right)$ and cellulose $\left(315-400^{\circ} \mathrm{C}\right)$ [25]. The DTG curve of the pistachio shell decomposition clearly demonstrates separated signals related to hemicellulose $T_{\max 1}$ and cellulose $T_{\max 2}$. On the other hand, the DTG curves of PN, WN and HN fillers exhibit a similar course involving clearly marked signal of the cellulose decomposition at the $347-365^{\circ} \mathrm{C}$ range as well as an inflection point with no additional maximum related to the hemicellulose degradation. Such a decomposition pathway might be related to the contents of the particular components in the natural fillers. As demonstrated in the Table 1 the pistachio shells has a higher content of hemicellulose and cellulose in comparison to the other considered natural fillers. The temperature range related to the lignin decomposition significantly overlaps with the decomposition of other components of the natural fillers and, therefore, was not observed as an individual signal in the DTG curve. The residue after combustion at $600^{\circ} \mathrm{C}$ was in the range of $20.3-29.6 \%$ for all the studied natural fillers.

\section{Analysis of the characteristic times of the foaming process}

The introduction of the natural fillers to the reaction composition resulted in a shorter foaming start time,
T a b l e 1. Chemical constitution of the nut shells $[5,17]$

\begin{tabular}{c|c|c|c|c}
\hline Filler & $\begin{array}{c}\text { Hemicelulose } \\
\text { wt } \%\end{array}$ & $\begin{array}{c}\text { Celulose } \\
\text { wt } \%\end{array}$ & $\begin{array}{c}\text { Lignin } \\
\text { wt } \%\end{array}$ & $\begin{array}{c}\text { Raw fat } \\
\text { wt } \%\end{array}$ \\
\hline PN & 26.8 & 40.0 & 35.7 & $1.5-1.7$ \\
WN & 28.6 & 34.7 & 37.3 & $5.1-5.5$ \\
HN & 20.3 & 37.8 & 38.7 & $1.5-1.9$ \\
PC & 29.9 & 42.7 & 15.2 & $2.6-4.1$ \\
\hline
\end{tabular}

T a b l e 2. Characteristic times of the RPUF foaming process

\begin{tabular}{c|c|c|c}
\hline Sample & Start time, s & Rise time, s & $\begin{array}{c}\text { Tack-free } \\
\text { time, s }\end{array}$ \\
\hline PU_REF & 45 & 138 & 170 \\
PU_PN & 32 & 168 & 190 \\
PU_WN & 34 & 165 & 188 \\
PU_HN & 30 & 160 & 181 \\
PU_PC & 40 & 145 & 163 \\
\hline
\end{tabular}

which indicates that the filler particles used enhance the reactivity of the polyurethane system in the initial stage of the foaming process, which might be related to their chemical structure (presence of the reactive hydroxyl groups) and the possible release of the volatile substances (Table 2). However, the rise time and the tackfree time were elongated after the introduction of the natural fillers, which might be related to the increased viscosity of the premixes. The obtained results indicate that the higher polyol premix viscosity correlates with the increasing characteristic times of the foaming process. This phenomenon was additionally confirmed by comparison to the literature report by Banik and Sain [26], who observed that foams manufactured using lower viscosity polyols were faster expanding than the similar materials utilizing higher viscosity substrates, which is in good agreement with our results.

\section{Analysis of the rigid polyurethane foams}

\section{Analysis of the foam surface morphology}

The scanning electron microscopy images of the developed materials showing the changes in the cellular structures depending on the foam composition have been presented in the Fig. 5.

Introduction of the natural fillers resulted in an increased structure anisotropy, higher content of the irregularly-shaped pores in comparison to the reference material as well as broader pore size distribution, which was illustrated in the Fig. 6 and confirmed by the standard deviation value from the mean equivalent diameter (Table 3). The PU_PN composite was characterized by the highest structural anisotropy among the investigates samples, which could be related to the significant increase in the polyol premix viscosity resulting from the introduction of the ground peanut shells. The PU_PC foam exhibited a predominant proportion of pores in the size range 150 

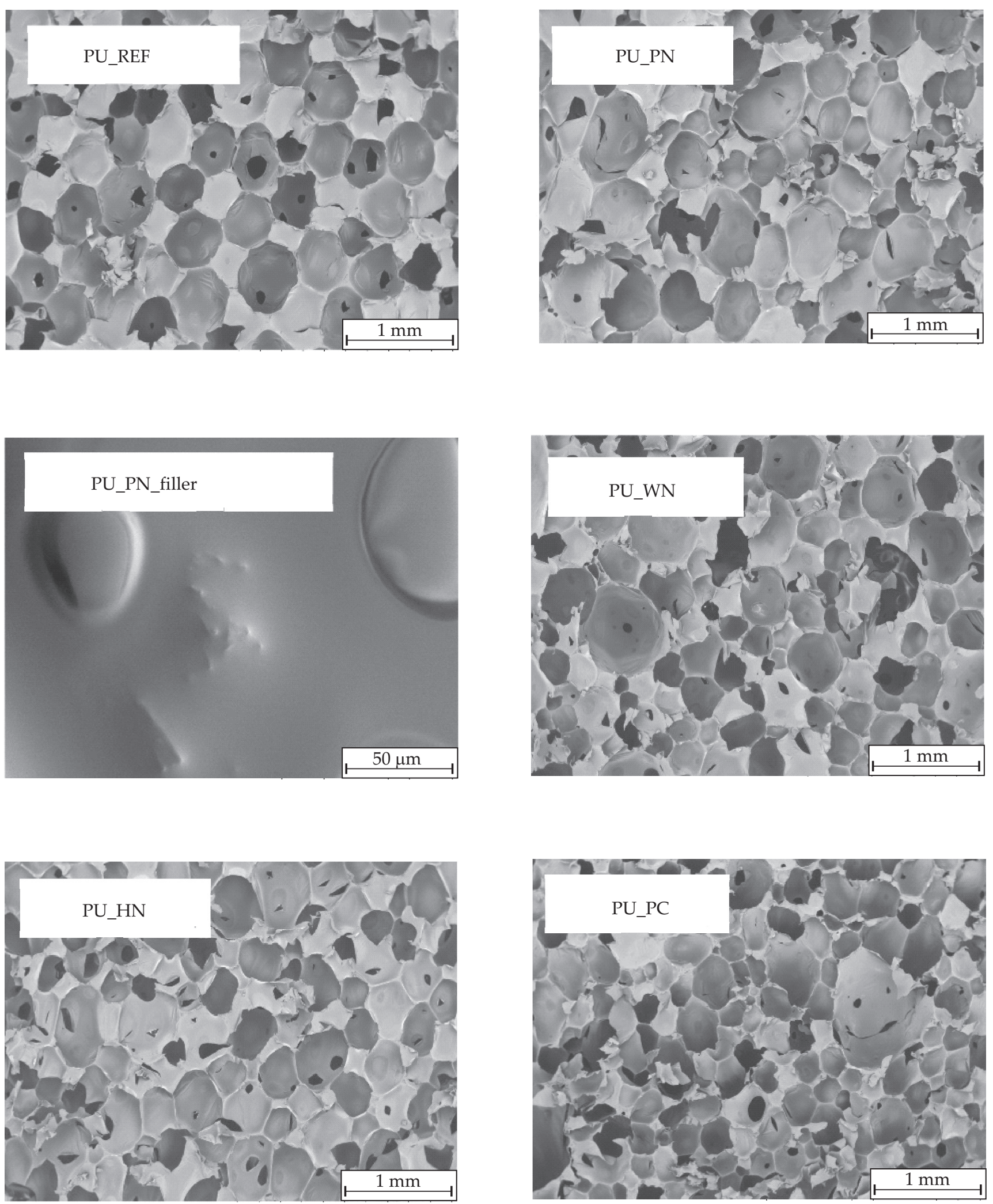

Fig. 5. SEM images of the RPUF 


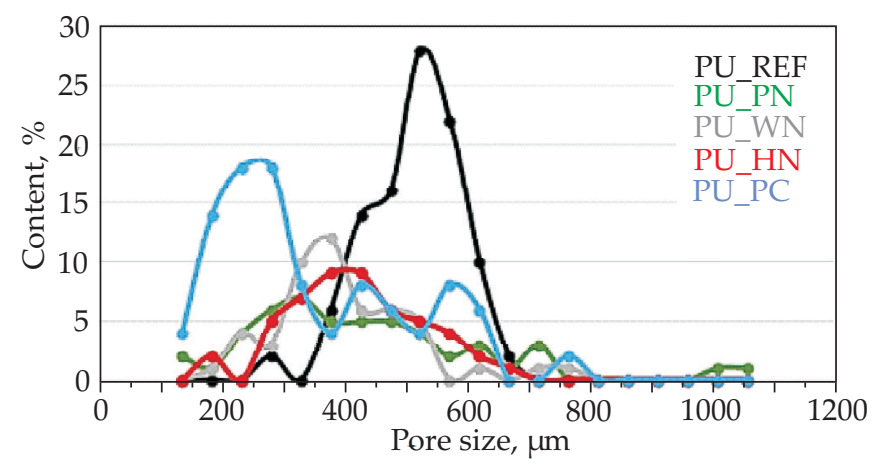

Fig. 6. The pore size distribution for the examined foams

$400 \mu \mathrm{m}$, however the determined standard deviation value from the mean equivalent diameter was relatively high due to the significant share of the large pores $c a .800 \mu \mathrm{m}$ in size. The pore size distributions for PU_HN and PU_WN composites are similar, which results from the comparable grain size of the introduced fillers. The PU_HN and PU_WN foams have exhibited a higher degree of structural arrangement in comparison to the PU_PC and PU_PN materials. Moreover, the imaging of the PU_PN revealed the presence of the agglomerated filler grains located in the pore walls, which also is a result of the increased viscosity of the polyol premix leading to the difficulties in the proper dispersion of the filler particles in the mixture, while other foams did not exhibit similar structural features. Overall the increased structural anisotropy of the studied composites might also be a result of the volatile substances released from the filler particles during the synthesis, including water, being a typical porophore in the polyurethane foaming process.

\section{Analysis of the chemical structure of the foams}

The FT-IR spectra of the reference foam as well as the composites involving the nut shells were demonstrated in the Fig. 7. The spectra were normalized with regard to the absorption band at $1595 \mathrm{~cm}^{-1}$ originating from the aromatic ring from the MDI. The results clearly indicate
T a b l e. 3. Mean equivalent diameters of the pores

\begin{tabular}{c|c}
\hline Sample & $\begin{array}{c}\text { Mean equivalent diameter } \\
\mu \mathrm{m}\end{array}$ \\
\hline PU_REF & $366 \pm 76$ \\
PU_PN & $410 \pm 197$ \\
PU_WN & $375 \pm 115$ \\
PU_HN & $397 \pm 107$ \\
PU_PC & $254 \pm 158$ \\
\hline
\end{tabular}

the presence of characteristic signals related to the polyurethanes (Table 4). No additional signals related to the introduction of plant-based fillers were observed in the obtained FT-IR spectra. However, some band shifts and band intensity changes related to the presence of natural fillers were visible, which indicates possible reactions involving the polymer matrix and the plant-based additives as well as absorption by the filler components. In the publication [25] it was reported that the three main components of biomass: cellulose, hemicellulose, lignin, are consisted of alkene, esters, aromatics, ketone and alcohol, with different oxygen-containing functional groups observed, e.g., $\mathrm{OH}\left(3400-3200 \mathrm{~cm}^{-1}\right), \mathrm{C}=\mathrm{O}\left(1765-1715 \mathrm{~cm}^{-1}\right)$, $\mathrm{C}-\mathrm{O}-\mathrm{C}\left(1270 \mathrm{~cm}^{-1}\right)$, and $\mathrm{C}-\mathrm{O}-(\mathrm{H})\left(\sim 1050 \mathrm{~cm}^{-1}\right)$. However, these bands significantly overlap with the FT-IR signals characteristic for polyurethanes. Comparison of the spectra of reference material (PU_REF) and the composites involving the nut shells lead to an observation that the intensity of absorption bands originating from the $\mathrm{N}=\mathrm{C}=\mathrm{O}$ group vibrations at $2277 \mathrm{~cm}^{-1}$ was diminished upon the natural filler introductions. This observation suggests that some of the excessive NCO groups have reacted with water released from the nut shells during the foaming process, as well as with the functional groups present in cellulose, hemicellulose and lignin. The analysis results clearly indicate that the intensity of the $2277 \mathrm{~cm}^{-1}$ absorption band is the lowest for the PU_HN and PU_WN composites, involving the use of the finest grain size of the fillers, which indicates that the increased fragmentation of the natural particles facil-

T a b l e 4. Analysis of signal displacements in FT-IR spectroscopy of characterized materials [27, 28]

\begin{tabular}{c|c|c|c|c|c}
\hline PU_REF & PU_PN & PU_WN & PU_HN & PU_PC & \\
\hline \multicolumn{6}{|c|}{ bond (vibration) } \\
\hline 99 & 3291 & 3295 & 3297 & 3299 & N-H (stretching) \\
2969 & 2973 & 2973 & 2969 & 2973 & C-H (asymmetric stretching) \\
2871 & 2869 & 2869 & 2868 & 2870 & C-H (symmetric stretching) \\
2277 & 2277 & 2277 & 2277 & 2277 & N=C=O (stretching) \\
1705 & 1705 & 1706 & 1707 & 1705 & C=O (stretching) \\
1595 & 1595 & 1595 & 1595 & 1595 & C=C (stretching) \\
1513 & 1514 & 1512 & 1510 & 1511 & N-H (bending) \\
1452 & 1451 & 1452 & 1452 & 1452 & C-H (deformation) \\
1411 & 1411 & 1411 & 1411 & 1411 & PIR (deformation) \\
1220 & 1220 & 1221 & 1221 & 1221 & C-N (stretching) \\
1071 & 1073 & 1073 & 1072 & 1072 & C-O (stretching) \\
\hline
\end{tabular}




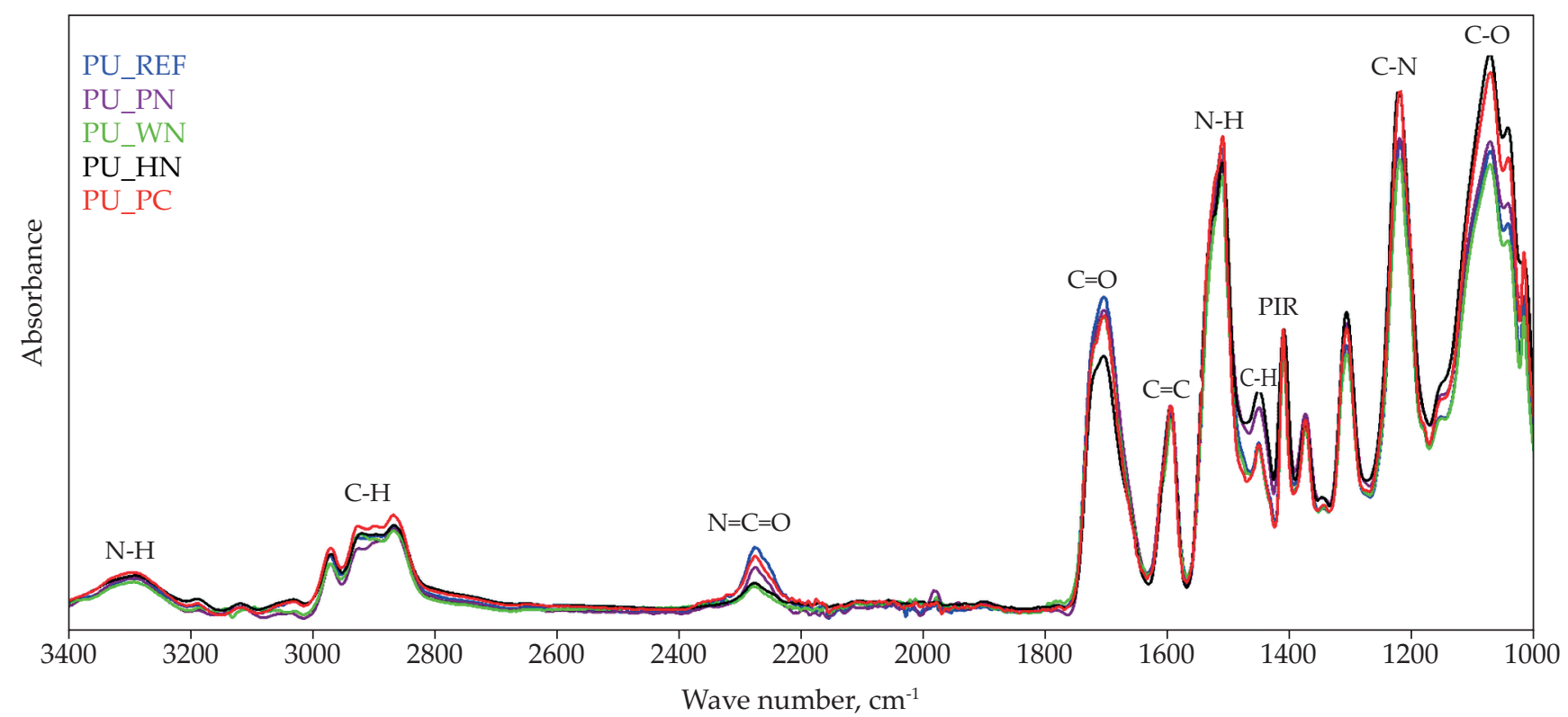

Fig. 7. FT-IR spectra of the RPUF

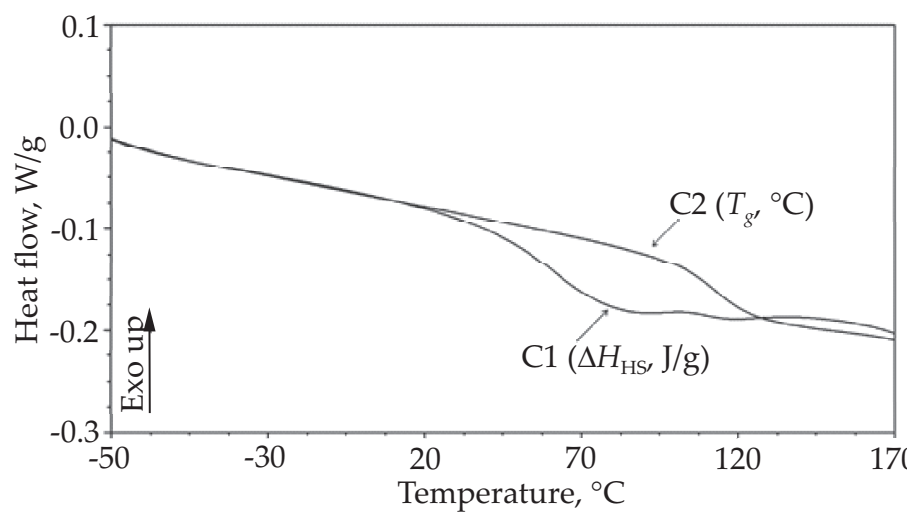

Fig. 8. DSC thermogram of the PU_PC material

T a b l e 5. The results of the DSC curve analysis of the examined materials

\begin{tabular}{c|c|c|c}
\hline Sample & $\Delta H_{\mathrm{HS}^{\prime}} \mathrm{J} / \mathrm{g}$ & $T_{g^{\prime}}{ }^{\circ} \mathrm{C}$ & $\Delta C_{p^{\prime}} \mathrm{J} /\left(\mathrm{g} \cdot{ }^{\circ} \mathrm{C}\right)$ \\
\hline PU_REF & 21.6 & 116.8 & 0.32 \\
PU_PN & 19.4 & 119.4 & 0.25 \\
PU_WN & 17.3 & 117.9 & 0.25 \\
PU_HN & 19.8 & 115.1 & 0.28 \\
PU_PC & 17.8 & 113.3 & 0.27 \\
\hline
\end{tabular}

itated the water release as well as enabled better access to the reactive functional groups on the particle surface.

\section{Thermal analysis of the rigid polyurethane foams}

The macromolecular structure of the developed PUR materials was also studied using the DSC technique, which allowed for determination of temperatures and thermal effects related to the physical transitions in examined foams. The DSC curves of the first heating cycle (C1) exhibited a presence of endothermal transition peak in the range of $30-140^{\circ} \mathrm{C}$, related to the rearrangement of the hard phase (Fig. 8). The results presented in Table 5 indicate that the $\Delta H_{\mathrm{HS}}$ (enthalpy change associated with rearrangement of hard segments) value decreased for the materials involving nut shells.

The change of the specific heat of glass transition during the second cycle of heating (C2) allows for the analysis of the segments mobility in the phase related to the observed transition. The studied composite materials differ significantly in the change of the specific heat of the phase transition determined in the second heating cycle, which indicates significant differences in the rigid phase structures. The rigid segments of the reference 70 sample (PU_REF) have been characterized with the highest mobility $\left[\Delta C_{p}=0.32 \mathrm{~J} /\left(\mathrm{g} \cdot{ }^{\circ} \mathrm{C}\right)\right]$, while introduction of the nut shells as natural filler particles results in a decrease in the rigid segments mobility, as demonstrated by the observed specific heat changes $\left[\Delta C_{p}=0.25-0.28 \mathrm{~J} /\left(\mathrm{g} \cdot{ }^{\circ} \mathrm{C}\right)\right]$. These results suggest that during the foam formation the NCO groups react with the functional groups present on the surface of the natural filler particles, leading to the additional reinforcement of the rigid segments. Introduction of the nut shells resulted in the minor changes in the glass transition temperatures of the foams.

All of the developed composite materials have been studied using the thermogravimetric analysis. Based on the TG curve the temperature of $2 \%$ mass loss $\left(T_{2 \%}\right)$ have been determined, which is related to the release of the easily volatilized substances including water. Moreover, the residue mass after combustion at $600^{\circ} \mathrm{C}$ has been determined for all samples (Table 6, Fig. 9). The reference foam (PU_REF) was characterized with higher $T_{2 \%}$ temperature in comparison to the RPUF composites involving the natural fillers, which confirms the presence of water and other volatile substances in the ground nut shell particles. Additionally, the residues after combustion at $600^{\circ} \mathrm{C}$ of the natural filler composites were ca. 1.1-1.6\% higher in comparison to the reference foam.

Based on the obtained DTG curves two distinct thermal degradation steps of the studied materials have been iden- 
$\mathrm{T}$ a b 1 e 6 . The results of thermogravimetric analysis

\begin{tabular}{c|c|c|c|c|c|c|c|c}
\hline Sample & $T_{2 \%}{ }^{\circ} \mathrm{C}$ & $T_{\max 1^{\prime}}{ }^{\circ} \mathrm{C}$ & $v_{\max 1^{\prime}} \% /{ }^{\circ} \mathrm{C}$ & $\Delta m_{1^{\prime}} \%$ & $T_{\max 2^{\prime}}{ }^{\circ} \mathrm{C}$ & $v_{\max x^{\prime}} \% /{ }^{\circ} \mathrm{C}$ & $\Delta m_{2^{\prime}} \%$ & $R\left(600^{\circ} \mathrm{C}\right), \%$ \\
\hline PU_REF & 220 & 321 & 1.31 & 84.1 & 472 & 0.06 & 4.6 & 7.3 \\
PU_PN & 210 & 324 & 1.16 & 82.0 & 471 & 0.06 & 5.3 & 8.8 \\
PU_WN & 218 & 326 & 1.22 & 83.2 & 473 & 0.06 & 5.0 & 8.4 \\
PU_HN & 209 & 322 & 1.25 & 84.1 & 473 & 0.05 & 4.9 & 8.4 \\
PU_PC & 216 & 321 & 1.24 & 82.6 & 471 & 0.06 & 5.5 & 8.9 \\
\hline
\end{tabular}

T a b l e 7. Apparent density, water absorption, dimensional stability and friability of the examined materials

\begin{tabular}{c|c|c|c|c}
\hline Sample & Apparent density, $\mathrm{kg} / \mathrm{m}^{3}$ & Water absorption, $\%$ & Dimensional stability, $\%$ & Friability, $\%$ \\
\hline PU_REF & $88 \pm 2$ & $3.0 \pm 0.2$ & 0.11 & 3.05 \\
PU_PN & $64 \pm 3$ & $5.3 \pm 0.6$ & 0.44 & 5.99 \\
PU_WN & $59 \pm 1$ & $3.8 \pm 0.2$ & 0.37 & 4.48 \\
PU_HN & $61 \pm 2$ & $3.8 \pm 0.3$ & 0.33 & 4.54 \\
PU_PC & $74 \pm 2$ & $4.2 \pm 0.5$ & 0.34 & 4.27 \\
\hline
\end{tabular}

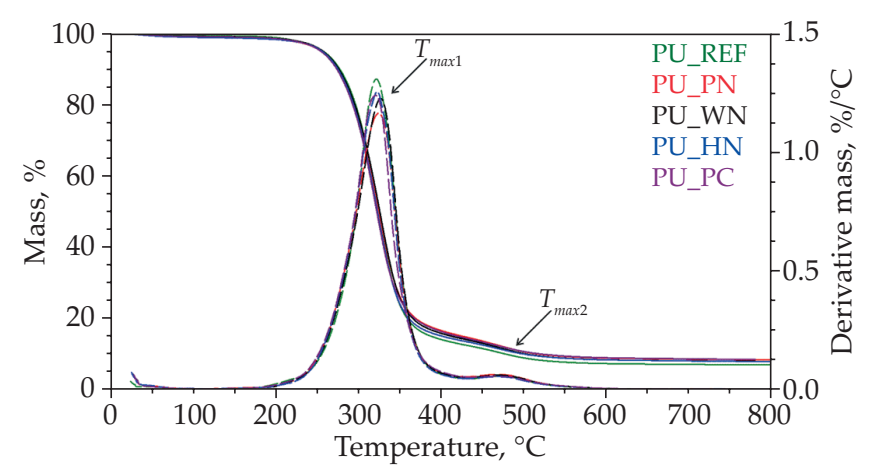

Fig. 9. TG and DTG thermograms of the examined materials

tified: the first on in the temperature range $230-395^{\circ} \mathrm{C}$, and the second in the range $395-550^{\circ} \mathrm{C}$. The first degradation stage is much more severe leading to the mass loss of $\Delta m_{1}=82.0-84.1 \%$, while the second degradation step was accompanied by further loss of $4.6-5.5 \%$ of the original sample mass. A single peak observed at lower temperature was related to the degradation of the rigid and flexible segments in the studied foams as well as most of the filler components. The first degradation peak in the examined foams exhibited the maximum degradation rate at $T_{\max 1}=321-326^{\circ} \mathrm{C}$ accompanied by the mass loss rate of $1.31 \% /{ }^{\circ} \mathrm{C}$ for the PU_REF material and lower values of $1.16-1.25 \% /{ }^{\circ} \mathrm{C}$ for the composites involving the natural fillers, which indicates that the presence of ground nut shell particles slowed down the thermal degradation process. The second degradation step is related to the slow decomposition of the products formed in the first degradation step with maximum degradation rate of $v_{\max 2}=$ $0.05-0.06 \% /{ }^{\circ} \mathrm{C}$ observed at $T_{\max 2}=471-473^{\circ} \mathrm{C}[29,30]$.

\section{Analysis of the physico-mechanical properties of the developed foams}

The conducted studies indicate that introduction of the plant-based fillers resulted in reduction of the final apparent density of the foams, despite the relatively high density of the filler materials $\left(1.33-1.44 \mathrm{~g} / \mathrm{cm}^{3}\right)$, determined using the pycnometric method [17]. This observation additionally corroborates the previous conclusions related to the release of additional porophores from the filler particles during the exothermic foam synthesis process. The highest amounts of water have been released from the natural fillers of the finest particle size $(\mathrm{HN}$, $\mathrm{WN}$ ), despite them containing similar total amounts of water to the filler material $\mathrm{PN}$, which is related to the facilitated access of the reaction mixture to the filler particle surface and lower viscosity of the polyol premix allowing for greater expansion of the polyurethane foam. The water absorption properties of the studied materials has significantly increased in the foams containing natural fillers, which might be a result of the disturbed foam structure as well as the chemical composition of the filler particles. The chemical composition analysis indicates that the peanut and pistachio shells exhibit higher content of the hydrophilic hemicellulose and cellulose as well as lower proportion of hydrophobic lignin compared to $\mathrm{HN}$ and $\mathrm{WN}$. Overall friability of the foams has increased upon introduction of the nut shell fillers, which is a result of the lower apparent density and higher structural anisotropy of these foams. The PU_PN composite was characterised with the highest value of friability among the studied materials, while all of the other composites exhibited comparable friability increase. All of the developed materials were characterised with high dimensional stability, with deformation values not exceeding $0.5 \%$.

\section{SUMMARY}

According to the conducted study the introduction of the natural fillers into the polyurethane composition was demonstrated to have a substantial impact on the properties of the obtained materials. Overall the results of the conducted study clearly indicate that the changes in viscosity of the polyol premixes were closely related to the 
size, shape and surface area of the natural filler particles, which had a significant effect on the characteristic times of the foaming process, foam surface morphology and the physico-mechanical properties of the developed porous polyurethane composites. Moreover, the influence of the chemical composition of the natural fillers on the thermal characteristics, application properties and chemical structure of the developed composite materials have been demonstrated. The results presented in this study suggest that the developed rigid polyurethane foam composites with nut shells might have valuable application properties, which could be further verified and precisely directed by additional application-oriented investigations, e.g. compressive strength, thermal conductivity and sound absorption tests.

The study has been financed by the National Research and Development Centre within the framework of the project EPURNAT PBS1/B5/18/2012.

\section{REFERENCES}

[1] Li P., Guo Y.B.B., Zhou M.W.W. et al.: International Journal of Impact Engineering 2019, 127, 154. https://doi.org/10.1016/j.ijimpeng.2018.12.009

[2] Prociak A., Rokicki G., Ryszkowska J.: „Materiały poliuretanowe", Wydawnictwo Naukowe PWN, Warszawa 2014.

[3] Agrawal A., Kaur R., Walia R.S.S.: European Polymer Journal 2017, 95, 255. https://doi.org/10.1016/j.eurpolymj.2017.08.022

[4] Wianowski L., Białkowska A., Dobrowolski L. et al.: Polimery 2020, 65, 83. https://dx.doi.org/10.14314/polimery.2020.2.1

[5] Ryszkowska J.: "Materiały poliuretanowe wytwarzane z zastosowaniem surowców odnawialnych", Oficyna Wydawnicza Politechniki Warszawskiej, Warszawa 2019.

[6] Członka S., Bertino M.F., Strzelec K.: Polymer Testing 2018, 68, 135. https://doi.org/10.1016/j.polymertesting.2018.04.006

[7] Paciorek-Sadowska J., Borowicz M., Czupryński B. et al.: Industrial Crops \& Products 2018, 126, 208. https://doi.org/10.1016/j.indcrop.2018.10.019

[8] Paciorek-Sadowska J., Czupryński B., Borowicz M. et al.: Polimery 2015, 60, 586. http://dx.doi.org/10.14314/polimery.2015.586

[9] Dhanola A., Bisht A.S., Kumar A. et al.: Materials Today 2018, 5, 17021.

https://doi.org/10.1016/j.matpr.2018.04.107

[10] Salasinska K., Ryszkowska J.: Composite Interfaces 2012, 19, 321. https://doi.org/10.1080/15685543.2012.726156

[11] Singh H., Singh T.: Materials Today 2019, 18, 5345. https://doi.org/10.1016/j.matpr.2019.07.560
[12] Domingos I., Ferreira J., Cruz-Lopes L. et al.: Food and Bioproduct Processing 2019, 115, 223. https://doi.org/10.1016/j.fbp.2019.04.002

[13] Miedzianowska J., Masłowski M., Strzelec K.: Technologia i jakość wyrobów 2018, 63, 45.

[14] Boonmee A., Jarukumjorn K.: Polymer Bulletin 2019, 17, 2097. https://doi.org/10.1007/s00289-019-02925-6

[15] Barczewski M., Andrzejewski J., Matykiewicz D. et al.: Polimery 2019, 64, 119. https://dx.doi.org/10.14314/polimery.2019.2.5

[16] Kuciel S.: „Kompozyty polimerowe na osnowie recyklatów z włóknami naturalnymi", Wydawnictwo Politechniki Krakowskiej, Kraków 2011.

[17] Sałasińska K.: „Kompozyty polimerowe z napełniaczami pochodzenia roślinnego otrzymywane z materiałów odpadowych", PHD thesis, Warszawa 2014.

[18] Antov P., Savov V., Neykov N.: International Journal Wood, Design \& Technology 2017, 6, 64.

[19] Kurańska M., Pinto J.A., Salach K. et al.: Industrial Crops \& Products 2020, 143, 1. https://doi.org/10.1016/j.indcrop.2019.111882

[20] Bryśkiewicz A., Zieleniewska M., Przyjemska K. et al.: Polymer Degradation and Stability 2016, 132, 32. https://doi.org/10.1016/j.polymdegradstab.2016.05.002

[21] Ribeiro Da Silva V., Mosiewicki M.A., Yoshida M.I. et al.: Polymer Testing 2013, 32, 665. https://doi.org/10.1016/j.polymertesting.2013.03.010

[22] Salasinska K., Mizera K., Barczewski M. et al.:Polymer Testing 2019, 79, 1. https://doi.org/10.1016/j.polymertesting.2019.106036

[23] Kużdżał E., Cichy B., Kużdżał E.: Chemik 2016, 70, 185.

[24] PL Pat. 233444 (2019).

[25] Yang H., Yan R., Chen H. et al.: Fuel 2007, 86, 1781. https://doi.org/10.1016/j.fuel.2006.12.013

[26] Banik I., Sain M.M.: Journal of Reinforced Plastics and Composites 2008, 27, 357. https://doi.org/10.1177/0731684407083955

[27] Jiao L., Xiao H., Wang Q. et al.: Polymer Degradation and Stability 2013, 98, 2687. https://doi.org/10.1016/j.polymdegradstab.2013.09.032

[28] Zieleniewska M., Leszczyński M.K., Kurańska M. et al.: Industrial Crops \& Products 2015, 74, 887. https://doi.org/10.1016/j.indcrop.2015.05.081

[29] Garrido M.A., Font R.: Journal of Analytical and Applied Pyrolysis 2015, 113, 202. https://doi.org/10.1016/j.jaap.2014.12.017

[30] Salasinska K., Borucka M., Leszczyńska M. et al.: Journal of Thermal Analysis and Calorimetry 2017, 130, 131. https://doi.org/10.1007/s10973-017-6294-4

Received 19 II 2020 